\title{
Sexta-feira Santa 14 de abril de 2017 Homilia da celebrậ̃ão da Paixão e Morte de Nosso Senhor Jesus Cristo
}

\author{
Pe. Edinei da Rosa Cândido
}

A leitura da Paixão do Senhor, segundo os quatro evangelistas, faz emergir uma estatística curiosa: no alto da cruz Jesus pronunciou sete frases ${ }^{1}$. Uma destas orientará nossa reflexão. Antes, porém, de revelá-la, é conveniente destacar o contexto que lhe dá o evangelista São João; é ele quem no-la revela. Acabamos de ouvir o seu relato da Paixão; ouçamos também dele o contexto da frase: "Junto da cruz de Jesus estavam sua mãe, a irmã de sua mãe, Maria, mulher de Cléofas e Maria de Magdala” (Jo 19, 25).

Há dez anos, em sua homilia de Sexta-feira Santa, proferida ao Santo Padre Bento XVI e à Cúria Romana, o pregador da Casa Pontifícia, o Frei Capuchinho Raniero Cantalamessa, focalizou essas mulheres que permaneceram no monte calvário, de pé, à hora da crucificação, junto da cruz com Jesus: sua mãe e a irmã de sua mãe, Maria de Cléofas e Maria Madalena. Sobre Maria, de maneira breve e sumária, simplesmente observou: Desta vez não falemos de Maria, sua Mãe. A sua presença no Calvário não requer explicações. Era "sua mãe" e isto explica tudo; as mães não abandonam um filho, embora tenha sido condenado à morte. Em seguida, proferiu mais uma das suas pérolas de retórica, beleza e, sobretudo, de profundidade espiritual. Era o dia 06 de abril de 2007, na Basílica de São Pedro, em Roma.

Hoje, 14 de abril de 2017, cá neste recanto da Ilha de Santa Catarina, nesta Igreja Matriz de Nossa Senhora das Necessidades, bem longe de lá, do Vaticano, no tempo e no espaço, celebrando, entretanto, o mesmo mistério, contrapomos as palavras do grande pregador. "Desta vez falemos de Maria, sua Mãe". Ouçamos, finalmente, a esperada frase do Evangelho de São João: Jesus, ao ver sua mãe e, ao lado dela, o

\footnotetext{
Cf. $\left.1^{a}\right)$ Lc 23,$34 ; 2^{a}$ ) Lc 23,$43 ; 3^{a}$ ) Jo $19,26-27 ; 4^{a}$ ) Mt 27,46 e Mc 15,$34 ; 5^{a}$ ) Jo 19,28 ;
} $\left.6^{a}\right)$ Jo 19,$\left.30 ; 7^{a}\right)$ Lc 23,46 . 
discípulo que ele amava, disse à mãe: "Mulher, eis o teu filho!” Depois disse ao discípulo: "Eis a tua mãe!” (Jo 19,26-27a).

Ele preferiu dirigir-se a Ela em expressão forte e universal: mulher, do mesmo modo como dissera nas bodas de Caná (cf. Jo 2,4). Foi o Evangelista que, por sua vez, na sua contextualização, a chamou de mãe. Mãe e mulher, ela é conhecida de nossas devoções, é moradora de nossas capelas e hospitais, é companheira de nossas procissões, do Senhor dos Passos e do Senhor Morto, é a mãe e Senhora das Dores. Recebemo-la com veneração e devoção.

(Entrada da imagem de Nossa Senhora das Dores, pelo corredor central, ao som do seu canto:)

(Virgem dolorosa, que aflitas chorais, repleta de angústias, bendita sejais, repleta de angústias, bendita sejais. Bendita sejais, Senhora das Dores.

Ouvi nossos rogos, mãe dos pecadores; ouvi nossos rogos, mãe dos pecadores).

Aqui é carregada no andor; ali estava de pé, junto da cruz. Com efeito, retomando a ideia do ilustre pregador, a sua presença no calvário não requer explicação. O fato de ser ela a mãe do condenado e estar ali junto a ele não requer explicação, mas faz toda a diferença: Eis a tua mãe. Sua compaixão maternal não podia deixá-la longe de seu Filho. Era sua mãe e, por desígnio do Filho e adoção do discípulo, tornou-se, nesse momento crucial, mãe da humanidade, de toda a Igreja, mãe universal. E a partir dessa hora, o discípulo a recebeu em sua casa (Jo 19,27b).

Ora, no alto do calvário, de pé junto da cruz, ela está por receber o seu último aguilhão, a punhalada final. Doravante seu imaculado coração, transpassado por sete espadas mortais, estará completo também nas dores. Já não é mais Maria de Nazaré, mas a Virgem Dolorosa. E é sob esse apanágio de dor que a vemos perto de nós, junto de nós, nossa mãe, neste momento, nesta hora, neste dia da morte de seu Filho Unigênito. Sua compaixão maternal não podia deixá-la longe de nós. E eis que, por mercê de Deus, veio, condoída de compaixão e sentimento maternos, viver entre nós.

Sexta-feira Santa do ano da Graça de Nosso Senhor Jesus Cristo de dois mil e dezessete: ano quase 2.000 da redenção; ano 300 da cheia de graça entre nós. Nossa padroeira e nossa rainha emerge do fundo de 
um rio, surge do lodo, desabrocha em flor do pântano, vitória régia. $\mathrm{E}$ aos seus tantos títulos, se lhe acresce um não menos belo: Aparecida.

$$
* * *
$$

Entre nós para nos proteger, com o seu manto,

para interceder, com o seu pranto,

para nos apontar Jesus: caminho, verdade e luz.

Imaculada, desde a sua conceição,

faz-se negra, liberta da escravidão,

Todos somos irmãos!

Mãe Aparecida,

mais do que n'outros tempos,

estamos à beira da estrada,

na encruzilhada,

sem rumo nem direção,

à beira rio, sem barco nem remo,

sem peixe, nem pesca, sob tua proteção.

Mais uma vez queremos reavivar a confiança,

cultivar a esperança.

Precisamos acertar o passo,

tomar tento e lançar-nos ao largo

com novas redes, coragem e muita fé,

como aqueles pescadores pobres:

Domingos Garcia, Felipe Pedroso e João Alves,

naquele memorável outubro de 1717.

Precisamos recomeçar.

Hoje, ao contemplar a Senhora da Dores,

te vemos com o manto azul,

decorado com nossa bandeira;

és tu que do Prata ao Amazonas, do mar às cordilheiras,

te apresentas enlutada junto da cruz, dolorida,

Aparecida, nesta Terra de Santa Cruz!

São estrelas do cruzeiro, do sul ao norte,

sacudidas pela fúria do dragão: morte.

Sociedade decaída, empobrecida, corrompida,

sem ética, nem moral!

Infância abandonada, velhice desprezada,

falência conjugal.

São balas perdidas, gente ferida, cabeças decepadas:

Que quadro de horrores!

Mulher, eis ai os teus filhos;

[Filho, eis aí os filhos de tua mãe.] 
Cuida deles com carinho, és fiel;

eles não têm mais vinho,

pouca água e pouco pão,

falta casa, moradia, direito de aposentadoria,

sobram vinagre e fel.

Alcança do Pai clemência, contra toda a violência,

és Rainha da paz.

Nunca se ouviu dizer que alguém que te tenha invocado

Deixaste de socorrer.

A ti, portanto, com toda a confidência,

Suplicamos, mãe, clemência,

com as súplicas mais suplicantes,

para tempos de grandes calamidades:

Mãe do bom conselho, rogai por nós,

Espelho de justiça, rogai por nós,

Saúde dos enfermos, rogai por nós,

Consoladora dos aflitos, rogai por nós,

Auxílio dos cristãos, rogai por nós.

Dentre todas preferida, és testemunha escolhida:

Rogai por nós: Vaso espiritual, Vaso honorífico,

Vaso insigne de devoção,

a recolher o sangue do calvário,

gota a gota, numerosas,

mais que as contas do rosário,

pérolas preciosas de nossa oração.

[...]

E às cinqüenta invocações da tua ladainha,

acrescentamos mais uma e imploramos,

com o coração palpitante:

Nossa Senhora Aparecida, mãe do povo brasileiro,

rogai e chorai por nós!

Fazei tudo o que ele vos disser; faça-se o que Deus quiser!

$* * *$

Junto da cruz, Maria encontra a coerência do seu sim irrestrito ao Pai e do seu seguimento incondicional ao Filho. É a hora suprema da dor. O soldado já se apresta e toma a lança; em breve se cumprirá a profecia de Simeão: Uma espada transpassará a tua alma (Lc 2,34b). E abre-se uma fenda no templo sagrado, coração rasgado; dilacerado o corpo de Cristo, carne da sua carne e sangue do seu sangue. 
É quando os sentidos desfalecem e apenas ousamos retocar as palavras dos judeus: "que este sangue puro e vinho novo, caia sobre nós e nossos filhos"; caia, como bênção, sobre todo o povo, que queremos sorvê-lo em profusão, enquanto ansiamos pelo vinho bom, prometido para o final da festa - ao pé da cruz! - e vislumbramos, inebriados, o vinho oferecido no cenáculo, na ceia derradeira, e ora colhido no receptáculo de todas as virtudes.

Deste lado traspassado, brota água viva que sacia, purifica e faz viver eternamente; o cálice transborda do altar da cruz, tributo precioso da nossa redenção. E eis que nasce a Igreja, nas núpcias do cordeiro imolado: sem mancha nem ruga, esposa tingida, de espinhos cingida, num pacto de dor.

Batismo, Eucaristia e Matrimônio, sacramentos de amor.

Proferido na Igreja Matriz de Nossa Senhora das Necessidades às $17 h 30$, em Santo Antônio de Lisboa,

Florianópolis (SC). 